\title{
AMBANG DETEKSI DAN PREFERENSI RASA UMAMI DALAM MODEL PANGAN
}

\section{[Detection and Preference Threshold of Umami Taste in Food Model]}

\author{
Dede R. Adawiyah" ${ }^{1,2) \star}$, dan Febby Setiawan ${ }^{1)}$ \\ 1) Departemen IImu dan Teknologi Pangan, Fakultas Teknologi Pertanian, Institut Pertanian Bogor, Bogor \\ 2) Southeast Asian Food and Agricultural Science and Tecnology Center, Institut Pertanian Bogor, Bogor \\ Diterima 06 April 2017 / Disetujui 05 Juni 2017
}

\begin{abstract}
Umami is one of the basic taste produced by monosodium glutamate (MSG). Generally, commercial MSG products did not specify the amount of a certain dose to produce palatable food. This problem could lead to uncontrolled and excessive use of MSG by consumers. The aim of this study was to determine the values for the detection and preference threshold of umami taste from commercial MSG products at different salt level. The detection threshold was determined using $R$-index method in salt solutions. The preference threshold was determined by using hedonic rating in food model. A food model selected in this case is spinach soup that is commonly consumed by Indonesian. The salt concentrations for detection and preference threshold experiment were 0.42 and $0.30 \mathrm{~g} / 100 \mathrm{~mL}$. Umami taste preference threshold value using Fechner's psychophysic equation for $0.30 \mathrm{~g} / 100 \mathrm{~mL}$ salt concentration is $0.25 \mathrm{~g} \mathrm{MSG} / 100 \mathrm{~mL}$, while for $0.42 \mathrm{~g} / 100 \mathrm{~mL}$ salt concentration, the umami taste preference threshold value is $0.06 \mathrm{~g} \mathrm{MSG} / 100 \mathrm{~mL}$. Detection threshold value using R-index method for $0.30 \mathrm{~g} / 100 \mathrm{~mL}$ salt concentration is $0.05 \mathrm{~g} \mathrm{MSG/100}$ $\mathrm{mL}$, while for $0.42 \mathrm{~g} / 100 \mathrm{~mL}$ salt concentration is $0.02 \mathrm{~g} \mathrm{MSG} / 100 \mathrm{~mL}$. Different salt concentrations leads to differences in the values of threshold preferences and detection threshold of the umami taste of MSG. Increasing salt concentration tends to decrease the detection and preference threshold of umami taste from MSG. This research results could be used as the basic information in food product formulation such as seasoning and condiment using mixtures of salt and MSG.
\end{abstract}

Keywords: detection threshold, MSG, preference threshold, r-index, umami

\begin{abstract}
ABSTRAK
Umami merupakan salah satu rasa dasar yang bersumber dari monosodium glutamat (MSG). Produk MSG komersial umumnya tidak mencantumkan jumlah atau dosis tertentu yang dibutuhkan untuk menghasilkan citarasa yang gurih. Permasalahan ini menyebabkan penggunaan MSG yang berlebihan dan tidak terkontrol oleh konsumen. Tujuan penelitian ini yaitu menentukan nilai ambang deteksi dan ambang preferensi rasa umami dari bahan MSG komersial pada konsentrasi garam yang berbeda. Ambang deteksi ditentukan menggunakan metode R-indeks dalam larutan garam. Ambang preferensi ditentukan menggunakan metode rating hedonik terhadap model pangan. Model pangan yang dipilih dalam hal ini adalah sayur bayam yang banyak dikonsumsi oleh masyarakat Indonesia. Konsentrasi garam yang digunakan adalah 0,30 dan $0,42 \mathrm{~g} / 100 \mathrm{~mL}$ dalam pelarut air. Nilai ambang preferensi rasa umami model psikofisik fechner pada konsentrasi garam $0,30 \mathrm{~g} / 100 \mathrm{~mL}$ adalah $0,25 \mathrm{~g} \mathrm{MSG} / 100 \mathrm{~mL}$, sedangkan pada konsentrasi garam $0,42 \mathrm{~g} / 100 \mathrm{~mL}$ adalah $0,06 \mathrm{~g} \mathrm{MSG} / 100 \mathrm{~mL}$. Nilai ambang deteksi dengan metode R-indeks pada konsentrasi garam $0,30 \mathrm{~g} / 100 \mathrm{~mL}$ yaitu $0,05 \mathrm{~g} \mathrm{MSG} / 100 \mathrm{~mL}$, sedangkan nilai R-indeks pada konsentrasi garam $0,42 \mathrm{~g} / 100 \mathrm{~mL}$ yaitu $0,01 \mathrm{~g} \mathrm{MSG} / 100 \mathrm{~mL}$. Perbedaan konsentrasi garam menyebabkan perbedaan nilai ambang preferensi dan ambang deteksi rasa umami dari MSG. Semakin tinggi konsentrasi garam cenderung menurunkan ambang deteksi dan ambang preferensi umami dari MSG. Manfaat dari penelitian ini dapat dijadikan sebagai dasar dalam formulasi produk pangan (seperti bumbu dan kondimen) yang menggunakan campuran garam dan MSG.
\end{abstract}

Kata kunci: ambang deteksi, ambang preferensi, MSG, r- indeks, umami

\section{PENDAHULUAN}

Umami merupakan salah satu rasa dasar yang dikenal luas sebagai rasa gurih oleh masyarakat

*Penulis Korespondensi:

E-mail: dede_adawiyah@ipb.ac.id
Indonesia. Rasa umami disebabkan oleh adanya komponen monosodium glutamat (MSG) dan ribonukelotida seperti garam 5-inosin-monofosfat (IMP) dan 5-guanin-monofosfat (GMP). Selain itu, glutamat bebas banyak terkandung pada produk pangan yang dikonsumsi sehari-hari seperti produk daging, buah-buahan, sayuran, dan bumbu masakan instan 
(Andarwulan et al., 2011); terasi atau belacan (Jinap et al., 2010); berbagai jenis jamur (mushrooms) (Zang et al., 2013); ikan dan produk perikanan (Sarower et al., 2012). Populin et al. (2007) melaporkan hasil survei kandungan asam glutamat bebas tertinggi ditemui pada produk yang tidak ditambahkan MSG adalah produk makanan mengandung protein terhidrolisis (sampai $129 \mathrm{mg} / 100 \mathrm{~g}$ ).

Berdasarkan Riset Kesehatan Dasar tahun 2007, MSG dikonsumsi oleh sekitar $77,8 \%$ populasi di Indonesia (Depkes, 2008). Andarwulan et al. (2011) menyatakan bahwa asupan asam glutamat bebas yang berasal dari pangan pada masyarakat di Jakarta dan Bogor yaitu 2013,76 dan 2068,97 $\mathrm{mg} / \mathrm{kap} / \mathrm{hari}$. Penggunaan MSG telah dinyatakan aman oleh Joint FAO/WHO Expert Committee on Food Additives (JECFA) sejak tahun 1988, serta menyatakan MSG sebagai "Acceptable Daily Intake (ADI) not specified" untuk asam glutamat dan garamnya (Jinap dan Hajeb, 2010). FAO/WHO mengatur regulasi penggunaan MSG pada produk pangan sebagai good manufacturing practice (GMP) atau sesuai dengan kebutuhan. Badan Pengawas Obat dan Makanan Republik Indonesia (BPOM RI) melalui PerKBPOM No. 232013 juga mengatur penambahan MSG sebagai penambah citarasa dalam produk pangan sebagai GMP. Akan tetapi sebagian besar masyarakat menganggap bahwa penggunaan MSG memberikan efek negatif terhadap kesehatan. Umumnya, produk MSG komersial tidak mencantumkan jumlah atau dosis tertentu yang dibutuhkan untuk menghasilkan citarasa yang gurih. Permasalahan ini menyebabkan penggunaan MSG yang berlebihan dan tidak terkontrol oleh konsumen. Hal ini terjadi karena belum diketahuinya dosis atau konsentrasi minimum dari MSG yang mulai bisa dideteksi (ambang deteksi) dan disukai oleh konsumen (ambang preferensi). Ambang deteksi umami didefinisikan sebagai konsentrasi MSG terendah yang sudah mulai dapat dideteksi dan berbeda dengan air. Dalam penelitian ini, ambang deteksi MSG ditentukan berbasis larutan garam karena dalam penggunaannya MSG biasanya bersamaan dengan garam (bukan sebagai larutan tunggal). Ambang preferensi didefinisikan sebagai konsentrasi MSG terendah yang sudah mulai disukai. Ambang preferensi lebih relevan dalam menilai sensasi rasa karena terdapat batasan dimana konsumen mulai menyukai suatu produk pangan pada konsentrasi tertentu tertentu (Hasanah et al., 2014). Lanfer et al. (2013) menyatakan bahwa stimulus ambang deteksi tidak relevan dengan sensasi rasa yang diterima dari produk pangan. Nilai ambang preferensi diperlukan sebagai informasi mengenai konsentrasi terkecil dari MSG yang mulai disukai konsumen. Nilai ambang sensori diperlukan untuk keperlukan formulasi produk pangan dan perubahan intensitas aroma dan rasa tertentu pada produk pangan (Senthil dan Bhat, 2010).

Penelitian ini bertujuan untuk menentukan menentukan nilai ambang deteksi rasa umami dari MSG dan nilai ambang preferensi rasa umami dari MSG dalam model pangan. Model pangan yang digunakan adalah sayur bening bayam pada dua konsentrasi garam yang berbeda.

\section{BAHAN DAN METODE}

\section{Bahan}

Bahan-bahan yang digunakan adalah air, sayur bayam, MSG (monosodium glutamat) komersial, garam meja komersial, bawang merah dan bawang putih yang diperoleh dari pasar komersial di daerah Bogor, Jawa Barat.

\section{Penentuan konsentrasi garam (Metode ranking hedonik; Meilgaard et al., 2007)}

Penentuan konsentrasi garam ditentukan menggunakan uji ranking hedonik pada produk sayur bening bayam. Penyiapan sayur bayam dilakukan dengan cara merebus $1 \mathrm{~L}$ air hingga mendidih, kemudian ditambahkan $10 \mathrm{~g}$ irisan bawang merah dan $5 \mathrm{~g}$ irisan bawang putih. Setelah perebusan dilanjutkan sampai sekitar 1 menit, ditambahkan garam sesuai perlakuan dan diaduk selama sekitar 20 detik. Sayur bayam $100 \mathrm{~g}$ kemudian ditambahkan dan dimasak selama 1-2 menit. Perlakuan konsentrasi garam yang ditambahkan terdiri dari lima tingkatan konsentrasi yaitu 0,$24 ; 0,30 ; 0,36 ; 0,42$ dan $0,48 \mathrm{~g} / 100 \mathrm{~mL}$. Sayur bayam didinginkan hingga mencapai suhu ruang sebelum disajikan kepada panelis. Sebanyak $\pm 30 \mathrm{~mL}$ sampel disajikan dalam cup saji yang telah diberi kode tiga digit angka acak. Panel yang digunakan adalah 30 panelis umum mahasiswa IPB dengan rentang usia 18-25 tahun yang biasa mengonsumsi sayur bening bayam. Panelis memulai pengujian dengan meminum sedikit air untuk menetralkan indera perasa. Pencicipan sampel dilakukan dengan mencicipi dari kiri ke kanan. Setelah mencicipi sampel, panelis diminta memberikan penilaian dengan cara membandingkan antar sampel dan mengurutkan sampel dari yang paling disukai (ranking 1) sampai ranking 5. Data respon panelis ditabulasikan dengan menggunakan Microsoft Excel 2013.Pengolahan data uji ranking dianalisis dengan uji Friedman pada taraf nyata 5\% menggunakan software SPSS v.20. Jika terdapat perbedaan signifikan, maka dilanjutkan dengan uji LSD Rank. 
Penentuan ambang preferensi rasa umami dari msg (metode rating hedonik; Meilgaard et al., 2007)

Pengujian preferensi dilakukan dengan menggunakan sayur bayam bening yang disiapkan menggunakan prosedur yang sama dengan tahap sebelumnya. Jumlah garam yang digunakan adalah dua konsentrasi garam yang terpilih dari tahapan sebelumnya. Variasi konsentrasi MSG yang digunakan adalah yaitu 0,$01 ; 0,02 ; 0,04 ; 0,08 ; 0,16$; dan $0,32 \mathrm{~g} / 100 \mathrm{~mL}$ dalam pelarut air. Panelis yang digunakan 70 orang panelis umum yang merupakan mahasiswa IPB dengan rentang usia 18-25 tahun dan terbiasa mengonsumsi sayur bening bayam. Kriteria lain yang digunakan adalah panelis tidak menolak MSG dalam konsumsi makanan seharihari. Sebanyak $\pm 30 \mathrm{~mL}$ sampel disajikan dalam cup. Sampel disajikan secara bersamaan pada panelis. Panelis memulai pengujian dengan meminum sedikit air untuk menetralkan indera perasa. Pencicipan sampel dilakukan dengan mencicipi dari kiri ke kanan. Setelah mencicipi sampel pertama, panelis diminta memberikan penilaian seberapa suka pada intensitas rasa tertentu dalam sampel tersebut. Sebelum mencoba sampel baru, panelis melakukan penetralan dengan meminum air. Penilaian dilakukan dengan cara memberikan skor kesukaan pada lembar uji yang memiliki skor penilaian 1-7 (1= sangat tidak suka, $2=$ tidak suka, $3=$ =agak tidak suka, $4=$ netral, $5=$ agak suka, $6=$ suka, $7=$ sangat suka).

Penentuan ambang preferensi dilakukan menggunakan pendekatan dua persamaan psikofifik yaitu model Steven (power law) dan Fechner (logaritmik) (Lawless, 2010). Persamaan Steven menurut adalah sebagai berikut:

$\mathrm{R}=\mathrm{k} \mathrm{C}^{\mathrm{n}}$

Persamaan tersebut diubah ke dalam persamaan logaritma sebagai berikut:

$\log R=n \log C+\log k$

Sedangkan persamaan Fechner adalah sebagai berikut:

$\mathrm{R}=\mathrm{k} \log \mathrm{C}$

Nilai $\mathrm{R}$ merupakan persepsi yang diberikan oleh panelis berupa skor hedonik; $\mathrm{C}$ adalah konsentrasi MSG; k dan $n$ merupakan konstanta. Ambang preferensi didefinisikan adalah konsentrasi pada saat nilai respon (R) mencapai nilai 5 (agak suka), ditetapkan menggunakan metode kurva preferensi, persamaan Fechner dan Steven.

\section{Penentuan ambang deteksi rasa umami dalam larutan garam (Metode R-indeks)}

Pengujian ambang deteksi rasa umami dilakukan pada larutan garam dengan konsentrasi yang sama dengan tahap preferensi rasa umami yang ditambahkan dengan enam variasi konsentrasi MSG. Panelis yang digunakan untuk pengujian ambang deteksi berjumlah 30 orang mahasiswa Departemen IImu dan Teknologi Pangan IPB yang sudah familiar dengan metode R-indeks, dan tidak menolak MSG dalam konsumsi makanan sehari-hari. Sampel pengujian terdiri dari referen $(R)$ berupa larutan garam dengan konsentrasi 0,30 dan $0,42 \mathrm{~g} / 100 \mathrm{~mL}$, dan enam sampel uji berupa larutan garam yang ditambahkan MSG dengan konsentrasi 0,01; 0,02; 0,04 ; 0,08; 0,16; dan 0,32 $\mathrm{g} / 100 \mathrm{~mL}$ larutan garam. Setiap wadah cup plastik diberi kode tiga digit angka acak.

Setiap panelis diberikan satu sampel referen (R) berupa larutan garam tanpa MSG dan enam sampel uji yaitu larutan garam dengan variasi konsentrasi MSG. Pertama, panelis diminta untuk mencicipi $\mathrm{R}$ untuk pengenalan, kemudian panelis melakukan penetralan dengan meminum air putih. Selanjutnya panelis mendapatkan sampel uji satu per satu untuk dievaluasi. Panelis diminta untuk membandingkan apakah sampel tersebut sama atau tidak dengan $\mathrm{R}$, dan seberapa yakin panelis terhadap perbedaan tersebut dengan pilihan respon yang terdiri dari 6 katagori seperti Tabel 1.

Tabel 1. Respon dan matriks data untuk uji R-indeks

\begin{tabular}{lcc}
\hline \multicolumn{1}{c}{ Respon } & Referens & Sampel \\
\hline $\begin{array}{l}\text { Sama, dan saya yakin } \\
\text { Sama, namun saya tidak terlalu } \\
\text { yakin }\end{array}$ & $\mathrm{a}$ & $\mathrm{g}$ \\
$\begin{array}{l}\text { Tidak tahu, namun saya } \\
\text { menduga sama }\end{array}$ & $\mathrm{c}$ & $\mathrm{i}$ \\
$\begin{array}{l}\text { Tidak tahu, namun saya } \\
\text { menduga berbeda }\end{array}$ & $\mathrm{d}$ & $\mathrm{j}$ \\
$\begin{array}{l}\text { Berbeda, namun saya tidak } \\
\text { terlalu yakin }\end{array}$ & $\mathrm{e}$ & $\mathrm{k}$ \\
Berbeda, dan saya yakin & $\mathrm{f}$ & $\mathrm{I}$ \\
\hline
\end{tabular}

Dalam satu seri uji terdapat satu sampel referen yang dijadikan sebagai sampel uji (blind control). Setiap pergantian sampel, panelis harus menetralkan indra pencicip. Analisis data R-indeks dilakukan dengan menghitung nilai persen $\mathrm{R}$-indeks pada masing-masing konsentrasi dengan menggunakan dengan rumus dari Lee dan Van Hout (2009) sebagai berikut:

$$
\text { R-indeks }(\%)=\frac{a(h+i+j+k+l)+b(1+j+k+l)+c(j+k+l)+d(k+l)+e(l)+0,5(a g+b h+c i+d j+e k+f l)}{(a+b+c+d+e)(g+h+i+j+k+l)} \times 100 \%
$$


Nilai abjad a - I mengacu pada Tabel 1. Nilai Rindeks hitung selanjutnya dibandingkan dengan nilai R-indeks kritis yang mengacu pada Tabel statistik yang dipublikasikan oleh Bi dan O'Mahony (2007).

\section{HASIL DAN PEMBAHASAN}

\section{Konsentrasi garam dalam model pangan}

Penetapan konsentrasi garam yang paling disukai pada model pangan (dalam hal ini digunakan sayur bayam bening) dilakukan menggunakan uji ranking hedonik. Hasil uji Friedman menunjukkan perbedaan konsentrasi garam yang signifikan antar sampel $(P<0,05)$. Selanjutnya dilakukan uji LSD Rank untuk menilai perbedaan antar sampel pada $\alpha$ $5 \%$. Berdasarkan Tabel 2 dapat dilihat bahwa konsentrasi garam 0,42 dan 0,48 g/100 mL merupakan sampel yang paling disukai dan tidak berbeda nyata pada taraf $5 \%$. Oleh sebab itu selanjutnya konsentrasi garam 0,42 g/100 $\mathrm{mL}$ selanjutnya digunakan untuk penentuan kadar MSG. Satu konsentrasi garam yang dipilih adalah konsentrasi garam yang lebih rendah dari 0,42 g/100 mL. Berdasarkan Tabel 2 , konsentrasi garam yang memberikan perbedaan jumlah peringkat yang signifikan adalah $0,30 \mathrm{~g} / 100$ $\mathrm{mL}$. Pengurangan kadar garam merupakan hal yang umum dilakukan dengan pertimbangan kesehatan. Dengan demikian pada penelitian selanjutnya digunakan dua konsentrasi garam yaitu 0,30 dan 0,42 $\mathrm{g} / 100 \mathrm{~mL}$.

Tabel 2. Hasil uji lanjut LSD Rank berbagai konsentrasi garam pada sampel sayur bayam bening

\begin{tabular}{cc}
\hline Konsentrasi Garam $(\mathrm{g} / 100 \mathrm{~mL})$ & Nilai Peringkat \\
\hline 0,48 & $2,26 \pm 1,57^{\mathrm{a}}$ \\
0,42 & $2,30 \pm 1,05^{\mathrm{a}}$ \\
0,36 & $3,07 \pm 0,87^{\mathrm{a}, \mathrm{b}}$ \\
0,30 & $3,63 \pm 1,24^{\mathrm{b}}$ \\
0,24 & $3,73 \pm 1,55^{\mathrm{b}}$ \\
\hline
\end{tabular}

Keterangan: Angka-angka pada kolom yang sama yang diikuti oleh huruf yang sama tidak berbeda nyata pada taraf uji 5\%

\section{Ambang preferensi rasa umami}

Gambar 1 memperlihatkan data tingkat kesukaan (hedonik) sayur bening dengan beberapa tingkat konsentrasi MSG pada dua konsentrasi larutan garam (0,30 dan $0,42 \mathrm{~g} / 100 \mathrm{~mL})$. Sayur bening dengan konsentrasi garam yang lebih tinggi $(0,42$ $\mathrm{g} / 100 \mathrm{~mL}$ ) secara keseluruhan memiliki nilai kesukaan yang lebih tinggi dibandingkan konsentrasi garam yang lebih rendah $(0,30 \mathrm{~g} / 100 \mathrm{~mL})$. Pada masingmasing konsentrasi garam dapat dilihat semakin tinggi konsentrasi MSG maka tingkat kesukaan semakin tinggi.

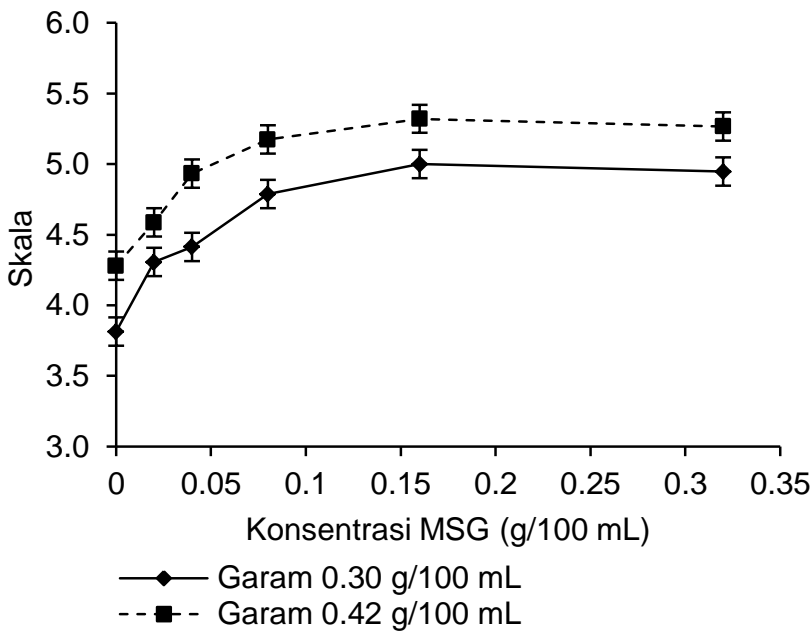

Gambar 1. Tingkat kesukaan rata-rata sayur bayam dengan konsentrasi garam 0.30 dan $0,42 \mathrm{~g} / 100 \mathrm{~mL}$ pada berbagai konsentrasi MSG

Penentuan ambang preferensi dilakukan menggunakan pendekatan dua persamaan psikofisik model Steven dan Fechner yang menjelaskan pengaruh sensasi fisik atau kimia (objektif) terhadap respon sensori (subjektif) (Lawless, 2010). Dalam hal ini dilakukan plot hubungan antara konsentrasi MSG dengan skala hedonik rata-rata. Pola linear untuk mode Steven diperolah dengan plot antara log konsentrasi MSG (log C) dengan log skor sensori $(\log S)$ (Gambar 2). Sedangkan pola liner untuk model Fechner diperoleh dari plot hubungan log konsentrasi MSG dengan skor sensori (Gambar 3).

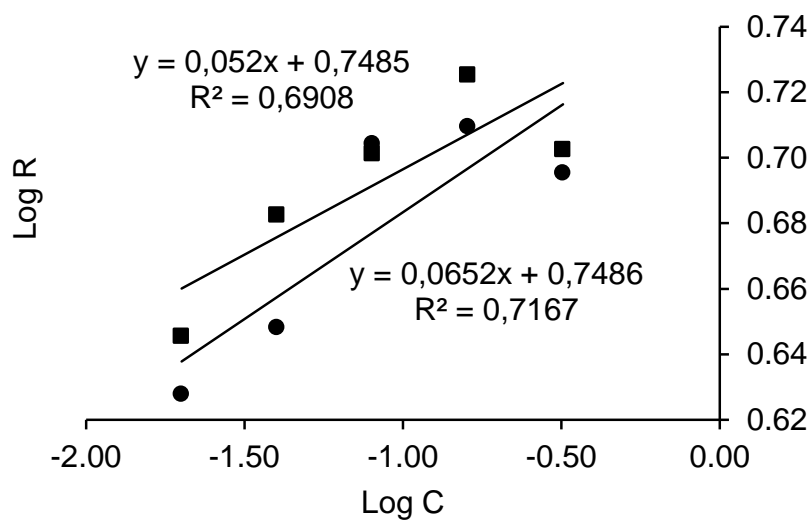

- garam $0.30 \mathrm{~g} / 100 \mathrm{~mL} \quad$ garam $0.42 \mathrm{~g} / 100 \mathrm{~mL}$

Gambar 2. Persamaan Steven pada konsentrasi garam 0,30 dan $0,42 \mathrm{~g} / 100 \mathrm{~mL}$

Persamaan regresi menghasilkan nilai koefisien determinasi $\left(R^{2}\right)$, slope dan intersep yang dapat dilihat pada Tabel 3 . Berdasarkan nilai koefisien determinasi yang diperoleh menunjukkan nilai yang cukup baik yaitu berkisar 0,69-0,78. Ambang pre- 
ferensi ditentukan dengan memasukkan nilai skala hedonik = 5 dari kedua persamaan yang diperoleh. Pada konsentrasi garam 0,30 g/100 mL diperoleh nilai ambang preferensi MSG 0,18-0,19 g/100 mL, sedangkan pada konsentrasi garam $0,42 \mathrm{~g} / 100 \mathrm{~mL}$ diperoleh nilai ambang preferensi MSG 0,08 $\mathrm{g}$ MSG/100 mL (Tabel 3).

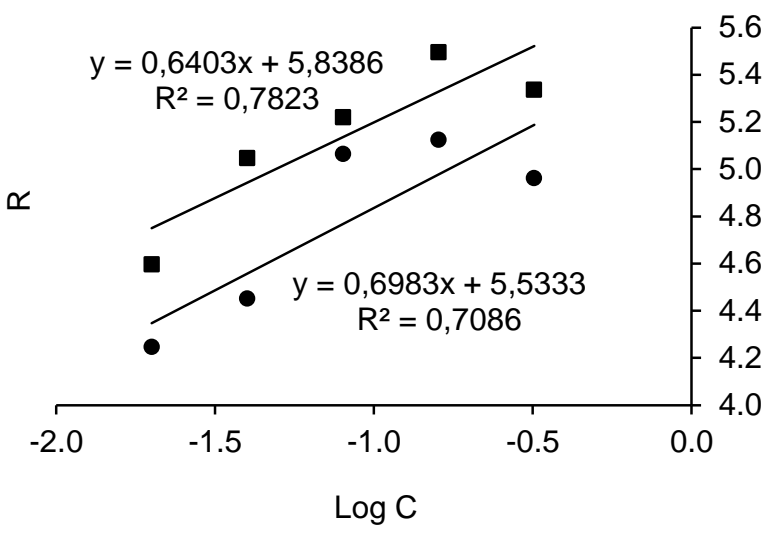

- garam $0.30 \mathrm{~g} / 100 \mathrm{~mL}$-garam $0.42 \mathrm{~g} / 100 \mathrm{~mL}$

Gambar 3. Persamaan Fechner pada konsentrasi garam 0,30 dan $0,42 \mathrm{~g} / 100 \mathrm{~mL}$

Penurunan konsentrasi garam menyebabkan terjadinya peningkatan konsentrasi MSG untuk mencapai ambang preferesi yang sama. Sebaliknya, dengan meningkatkan konsentrasi garam pada tingkatan konsumsi normal, maka konsentrasi MSG yang diperlukan menjadi lebih sedikit untuk mencapai nilai preferensi yang sama. Garam dan MSG memiliki efek sinergis dalam meningkatkan citarasa pada konsentrasi tertentu, sehingga dapat menurunkan jumlah penggunaan keduanya untuk mendapatkan sensasi yang sama. Negara Jepang mengurangi asupan garam yang tinggi dengan menambahkan umami yang berasal dari MSG (Wakita et al., 2013). Barylko-Pikielna dan Kostyra (2007) melaporkan bahwa penambahan senyawa pemberi rasa umami (MSG, IMP dan GMP) memberikan efek hedonik yang bervariasi dan dinamis tergantung dari matriks pangan yang digunakan (product dependent).

\section{Ambang deteksi rasa umami}

Ambang deteksi adalah konsentrasi terendah zat dalam media yang berkaitan dengan intensitas fisik terendah dimana stimulus dapat dideteksi (ASTM, 2011). Dalam penelitian ini, ambang deteksi rasa umami didefinisikan sebagai konsentrasi MSG terendah yang mulai dapat dideteksi adanya perbedaan sensasi rasa dengan larutan referen. Dalam hal ini larutan referen yang digunakan adalah larutan garam dengan konsentrasi 0,30 dan 0,42 g $\mathrm{NaCl} / 100 \mathrm{~g} / \mathrm{mL}$ (tanpa MSG). Ambang deteksi umumnya ditentukan dengan metode standar yang digunakan untuk penentuan ambang sensori yaitu teknik 3-AFC (three alternative forced choice) ascending method of limit yang mengacu pada metode standar American Society for Testing and Material, ASTM 2011 (ASTM E679, 2004; ASTM E1432, 2004) dan Lawless (2010). Metode alternatif yang juga dapat menentukan ambang deteksi suatu stimulus rasa selain 3-AFC adalah R-indeks. Metode $\mathrm{R}$-indeks merupakan teknik data analisis yang memperhitungkan adanya indeks diskriminasi untuk membedakan seberapa besar perbedaan antar dua sampel (Kemp et al., 2009). Robinson et al. (2005) menyatakan bahwa metode signal detection rating (R-indeks) memiliki beberapa keuntungan dibandingkan metode ASTM 3-AFC ascending limit yaitu penyiapan sampel lebih sedikit dan sensitivitas panelis tidak bergantung dari kriteria lokasi atau penempatan sampel. Dengan demikian, menggunakan metode ini R-indeks menjadi alternatif dalam pengukuran nilai ambang dengan penyajian sampel yang lebih sedikit, serta dapat menghemat waktu dan biaya pengujian.

Umumnya, dalam pengujian ambang deteksi, sampel uji yang digunakan lebih dari satu. Pada uji ini digunakan enam konsentrasi sampel uji yaitu 0,$01 ; 0,02 ; 0,04 ; 0,08 ; 0,16$; dan 0,32 g MSG/100 $\mathrm{mL}$ dalam pelarut garam. Nilai $\mathrm{R}$-indeks yang diperoleh kemudian dibandingkan dengan nilai kritis yang diperoleh dari tabel $\mathrm{R}$-indeks. Jika nilai $\mathrm{R}$ indeks lebih besar dari nilai kritis, maka artinya sampel uji dapat dibedakan secara signifikan dengan referen atau larutan dasar. Metode $\mathrm{R}$-indeks memiliki berbagai keunggulan dan lebih mudah dalam preparasi sampel dibandingkan dengan metode ASTM 3-AFC. Metode ini dapat mengurangi kejenuhan panelis, lebih efisien dalam penyajian sampel, dan mengurangi biaya pengujian.

Tabel 3. Parameter persamaan regresi dan nilai ambang preferensi rasa umami dengan persamaan Steven dan Fechner

\begin{tabular}{cccccc}
\hline $\begin{array}{c}\text { Konsentrasi Garam } \\
(\mathrm{g} / 100 \mathrm{~mL})\end{array}$ & Koefisien/Slope & Intersep & $\mathrm{R}^{2}$ & Persamaan Regresi & $\begin{array}{c}\text { Ambang Preferensi } \\
(\mathrm{g} \mathrm{MSG} / 100 \mathrm{~mL}\end{array}$ \\
\hline 0,30 (Steven) & 0,065 & 0,749 & 0,72 & $\mathrm{y}=0,0652 \mathrm{x}+0,7486$ & $0,18 \pm 0,25$ \\
0,30 (Fechner) & 0,698 & 5,533 & 0,71 & $\mathrm{y}=0,6983 \mathrm{x}+5,5333$ & $0,19 \pm 0,38$ \\
0,42 (Steven) & 0,052 & 0,748 & 0,69 & $\mathrm{y}=0,052 \mathrm{x}+0,7485$ & $0,08 \pm 0,14$ \\
0,42 (Fechner) & 0,640 & 5,838 & 0,78 & $\mathrm{y}=0,6403 \mathrm{x}+5,8386$ & $0,08 \pm 0,18$ \\
\hline
\end{tabular}


Gambar 4 menunjukkan cara penentuan nilai ambang deteksi menggunakan nilai R-indeks untuk enam konsentrasi MSG. Nilai kritis yang diperoleh dari tabel R-indeks untuk jumlah panelis 30 orang dan $\alpha=0,05$ adalah $13,99 \%$. Sampel dikatakan signifikan berbeda dengan referen jika \%R-indeks pada nilai kritis $50 \%$ lebih besar dari $63,99 \%$ yang ditunjukkan dengan garis lurus pada Gambar 4. Nilai ambang deteksi ditentukan pada saat nilai R-indeks hitung mencapai nilai R-indeks kritis $(63,99 \%)$ atau dengan melakukan interpolasi linear untuk mendapatkan nilai konsentrasi MSG pada saat nilai Rindeks $63,99 \%$. Nilai ambang deteksi dengan metode R-indeks pada konsentrasi garam $0,30 \mathrm{~g} / 100 \mathrm{~mL}$ adalah $0,05 \mathrm{~g} \mathrm{MSG} / 100 \mathrm{~mL}$, sedangkan nilai $\mathrm{R}$ indeks pada konsentrasi garam 0,42 g/100 mL adalah 0,02 g MSG/100 mL. Informasi ambang deteksi tersebut dapat digunakan untuk menentukan formulasi minimum dalam menghasilkan rasa gurih tanpa menambahkan MSG secara berlebihan.

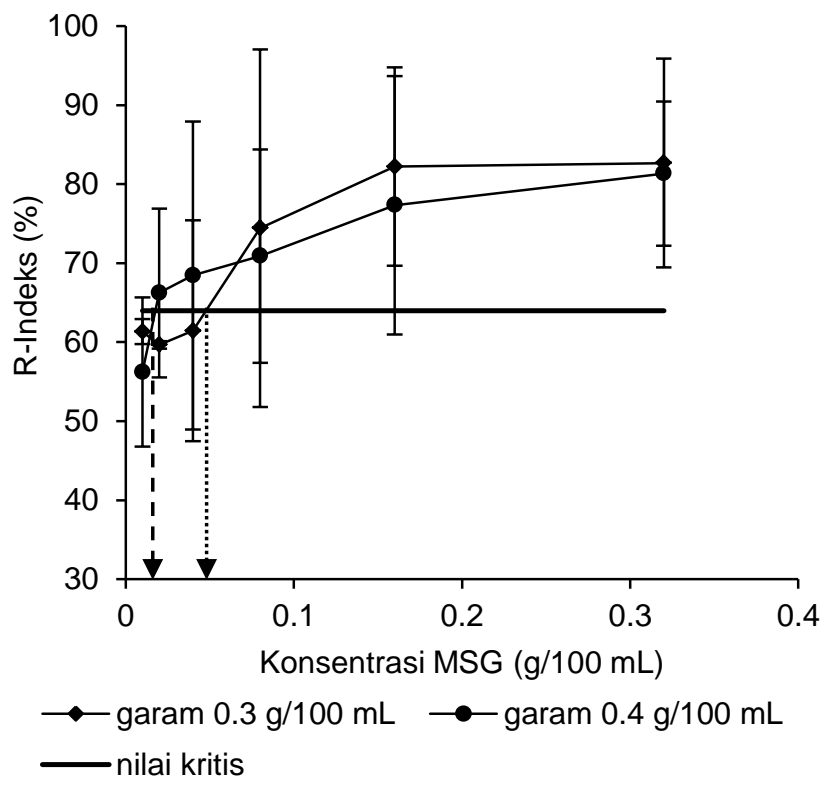

Gambar 4. Penentuan ambang deteksi MSG pada konsentrasi garam $0,30(\cdots)$ dan 0,42 $(-\rightarrow) \mathrm{g} / 100 \mathrm{~mL}$ menggunakan nilai Rindeks pada $\alpha 5 \%$

Pada konsentrasi garam yang lebih tinggi, maka diperoleh nilai ambang deteksi rasa umami dari MSG menjadi semakin kecil. Hal ini sejalan dengan nilai ambang preferensi yang menunjukkan kecenderungan yang sama. Dengan meningkatkan jumlah garam maka konsentrasi MSG untuk menghasilkan rasa umami menjadi lebih kecil. Demikian juga sebaliknya, jika jumlah garam diturunkan maka diperlukan jumlah jumlah MSG yang lebih banyak untuk dideteksi dan disukai oleh panelis. Hal tersebut membuktikan bahwa ada interaksi yang ter- jadi antara garam dengan MSG, sehingga penggunaan garam mampu menurunkan jumlah MSG yang ditambahkan untuk dapat dideteksi sebagai rasa umami dalam produk pangan. Keast dan Breslin (2003), menjelaskan bahwa dalam pencampuran 2 komponen rasa, terdapat beberapa kemungkinan interaksi yaitu enhancement dan suppression. Peningkatan konsentrasi garam dari 0,30 menjadi $0,42 \mathrm{~g} / 100 \mathrm{~mL}$ memberikan efek enhancement terhadap rasa umami. Penambahan glutamat dapat mereduksi jumlah garam dalam produk pangan (Jinap dan Hajeb, 2010). Ventanas et al. (2010) menyatakan bahwa garam mampu meningkatkan persepsi intensitas atribut bau dan flavor yang disebabkan oleh fenomena salting-out.

Satoh-kuriwada et al. (2012) melakukan pengukuran ambang pengenalan rasa umami dari MSG menggunakan metode filter paper disc secara langsung dikontakkan pada 3 area di lidah (anterior, posterior dan soft palate), dan mendapatkan nilai ambang pengenalan rasa umami dari MSG adalah 5-10 mM pada bagian posterior dan soft palate, serta $10-50 \mathrm{mM}$ pada bagian anterior lidah. Nilai ambang deteksi rasa umami dari MSG yang diperoleh dari penelitian ini adalah $0.05 \mathrm{~g} / 100 \mathrm{~mL}$ atau $3 \mathrm{mM}$ pada larutan garam $0,3 \%$ dan $0,01 \mathrm{~g} / 100 \mathrm{~mL}$ atau $0,6 \mathrm{mM}$ pada larutan garam $0,42 \%$. Nilai ambang deteksi yang diperoleh lebih kecil dari ambang pengenalan yang didapatkan oleh Satoh-kuriwada et al. (2012). Secara definisi, ambang deteksi memang akan memilki nilai yang lebih kecil dari ambang pengenalan. Pada ambang deteksi biasanya panel belum begitu jelas mendeteksi suatu rasa (baru samar-samar), akan tetapi sudah berbeda dengan air. Sedangkan ambang pengenalan didefinisikan sebagai konsentrasi dimana suatu rasa sudah mulai jelas dikenali sebagai rasa umami.

\section{KESIMPULAN}

Ambang preferesi dan ambang deteksi rasa umami dari MSG sangat ditentukan oleh konsentrasi garam yang digunakan sebagai larutan dasar. Nilai ambang preferensi rasa umami pada konsentrasi garam $0,30 \mathrm{~g} / 100 \mathrm{~mL}$ adalah $0,18 \mathrm{~g} \mathrm{MSG} / 100 \mathrm{~mL}$, sedangkan pada konsentrasi garam $0,42 \mathrm{~g} / 100 \mathrm{~mL}$ adalah $0,08 \mathrm{~g} \mathrm{MSG} / 100 \mathrm{~mL}$. Nilai ambang deteksi dengan metode $\mathrm{R}$-indeks pada konsentrasi garam $0,30 \mathrm{~g} / 100 \mathrm{~mL}$ yaitu $0,05 \mathrm{~g} \mathrm{MSG} / 100 \mathrm{~mL}$ larutan garam, sedangkan nilai R-indeks pada konsentrasi garam $0,42 \mathrm{~g} / 100 \mathrm{~mL}$ yaitu $0,02 \mathrm{~g} \mathrm{MSG} / 100 \mathrm{~mL}$ larutan garam. Perbedaan konsentrasi garam menyebabkan perbedaan nilai ambang preferensi dan ambang deteksi rasa umami dari MSG. Peningkatan jumlah garam dapat menurunkan konsentrasi MSG untuk dideteksi dan mulai disukai oleh panelis. 


\section{DAFTAR PUSTAKA}

Andarwulan N, Nuraida L, Madanijah S, Lioe HN, Zulaikhah. 2011. Free glutamate content of condiment and seasonings and their intake in Bogor and Jakarta, Indonesia. Food Nutr Sci 2: 764-769. DOI: 10.4236/fns.2011.27105.

[ASTM] American Society of Testing and Materials (US). 2011. ASTM E679-04: Standard Practice for Determination of Odor and Taste Thresholds by a Forced-choice Ascending Concentration Series Method of Limit. West Conshohocken (US): ASTM International. DOI: 10.1520/E067904R11.

Barylko-Pikielna N, Kostyra E. 2007. Sensory interaction of umami substances with model food matrices and its hedonic effect. Food Qual Prefer 18: 751-758. DOI: 10.1016/j.foodqual. 2007.01.002.

Bi J, O'Mahony M. 2007. Update and extended tabel for testing the significance of the R-index. J Sens Stud 22: 713-720. DOI: 10.1111/j.1745459X.2007.00132.x.

[BPOM] Badan Pengawas Obat dan Makanan RI. 2013. Peraturan Kepala Badan Pengawas Obat dan Makanan Republik Indonesia No. 13 Tahun 2013 tentang Batas Maksimum Penggunaan Bahan Tambahan Pangan Penguat Rasa. Jakarta (ID): BPOM.

[Depkes] Departemen Kesehatan. 2008. Riset Kesehatan Dasar (Riskedas) 2007. Badan Penelitian dan Pengembangan Kesehatan, Departemen Kesehatan, RI. Jakarta.

Hasanah U, Adawiyah DR, Nurtama B. 2014. Preferensi dan ambang deteksi rasa manis dan pahit: pendekatan multikultural dan gender. $\mathrm{J}$ Mutu Pangan 1: 1-8.

Jinap S, Hajeb R. 2010. Research review: Glutamate. Its application in food and contribution to health. Appetite 55: 1-10. DOI: 10.1016/J.appet. 2010.05.002.

Jinap S, llya-Nur AR, Tang SC, Hajeb R, Shahrim K, Khairunnisak M. 2010. Sensory attributes of dishes containing shrimp paste with different concentration of glutamate and 5'-nucleotide. Appetite 55: 238-244. DOI: 10.1016/j.appet.20 10.06.007.

Keast RSJ, Breslin PAS. 2003. An overview binnary taste-taste interactions. Food Qual Prefer 14: 111-124. DOI: 10.1016/S0950-3293(02)001106.

Kemp S, Hollowood T, Hort J. 2009. Sensory Evaluation A Practical Handbook. p 174-177. New York (US): John Wiley and Sons Ltd. Publication.
Lanfer A, Bammann K, Knof K, Buchecker K, Russo $\mathrm{P}$, Veidebaum $\mathrm{T}$, Kourides $\mathrm{Y}$, de Henauw $\mathrm{S}$, Molnar D, Bel-Serrat S, Lisser L, Wolfgang. 2013. Predictors and correlates of taste preferences in European children: The IDEFICS study. Food Qual Prefer 27: 128-136. DOI: 10.1016/j.foodqual.2012. 09.006.

Lawless HT. 2010. A simple alternative analysis for threshold data determined by ascending forcedchoice methods of limits. J Sens Stud 25: 332346. DOI: 10.1111/j.1745-459X.2009.002 62.x.

Lee HS, Van Hout D. 2009. Quantification of sensory and food quality: R-index analysis. J Food Sci 6: R57-R64. DOI: 10.1111/J.17503841.200 9.01204.x

Meilgaard M, Civille GV, Carr BT. 2007. Sensory Evaluation Techniques. 271-281. Boca Raton (FL) New York: CRC Press.

Populin T, Moret S, Truant S, Conte LS. 2007. A survet on the presence of free glutamic acid in foodstuffs, with and without added monosodium glutamate. Food Chem 104: 1712-1717. DOI: 10.1016/j.foodchem.2007.03.034.

Robinson KM, Klein BP, Lee SY. 2005. Utilizing the $\mathrm{R}$-index for threshold testing in model caffeine solutions. Food Qual Prefer 16: 283-289. DOI: 10.1016/j.foodqual.2004.05.001.

Sarower MG, Md Hasanuzzaman AF, Biswas M, Abe H. 2012. Taste producing component in fish and fisheries products: A review. Int $\mathrm{J}$ food Ferment Technol 2: 113-121.

Satoh-Kuriwada S, Kawai M, Noriakishoji, Sekine Y, Uneyama H, Sasano T. 2012. Assesment of umami taste sensitivity. J Nutr Food Sci S10. DOI: 10.4172/2155-9600.S10-003.

Senthil A, Bhat KK. 2010. Best estimated taste detection threshold for cardamom (Elettaria cardamomum) aroma in different media. J Sens Stud 26: 48-53. DOI: 10.1111/j.1745-459X.20 10.00320.x.

Ventanas S, Mustonen S, Puolane E, Tuorila H. 2010. Odour and flavor perception on flavoured model systems: influence of sodium chloride, umami compounds and serving temperature. Food Qual Prefer 21: 453-462. DOI: 10.1016/j. foodqual.2009.11.003.

Wakita A, Sarukura N, Kimura Y, Shikanai S, Iwamoto T. 2013. Dietary salt and health: umami seasoning as an attempt to reduce salt intake. J Nutr Food Sci S10:008. DOI: 10.4172/ 2155-9600.S10-008.

Zang Y, Venkitasanmy C, Pan Z, Wang W. 2013. Recent development of umami ingredients of edible mushrooms - A review. Trends Food Sci Technol 33: 78-92. DOI: 10.1016/j.tifs.2013. 08.002 . 